\title{
C-REACTIVE PROTEIN IN RHEUMATIC HEART DISEASE
}

BY

\author{
R. D. EASTHAM, P. SZEKELY, AND K. DAVISON
}

From the Cardiovascular Department and Department of Pathology, Newcastle General Hospital, Newcastle-on-Tyne

The behaviour of the C-reactive protein as a measure of rheumatic activity has been the subject of several publications. Most investigators have studied the C-reactive protein test in cases of frank rheumatic fever in children and there have been only isolated observations on its value in the assessment of rheumatic activity in chronic rheumatic heart disease in adults. Elster, Braunwald, and Wood (1956) suggested that the test might be helpful in the detection of subclinical rheumatic activity in such patients. Although recurrences of rheumatic fever become less frequent with advancing age, it is possible that rheumatic activity of this kind is more common in adults than is generally appreciated (Roberts, 1954; Biörck, 1955; Mortimer and Rammelkamp, 1956). Recently, Roberts (1954) stressed again that the course of rheumatic heart disease can be most appropriately described as polycyclic, phases of activity alternating with periods of apparent clinical quiescence. With this idea in mind, we have studied a group of unselected patients with rheumatic fever and rheumatic heart disease and have attempted to determine the value and limitations of the $\mathrm{C}$-reactive protein test as a measure of rheumatic activity at various stages of the disease process.

\section{Material and Method}

The 215 patients studied were divided into four groups according to the clinical picture:

(A) Twelve patients with active rheumatic carditis satisfying the criteria of Jones (1944); six of these were experiencing their first attack of carditis and the other six already had established valvular lesion.

(B) 61 patients with chronic rheumatic heart disease in whom the presence of rheumatic activity could not be established on clinical grounds. These patients were grouped together because they all showed signs of progressive deterioration and had either experienced cardiac failure before this study was undertaken, or were suffering from it while the study was being carried out.
(C) 134 Patients with chronic rheumatic heart disease who were considered clinically to be in a quiescent stage. These patients had never had cardiac failure and the size of the heart had remained unchanged for several years.

(D) Eight patients with chorea and no other rheumatic manifestation.

426 C-reactive protein tests were carried out on these 215 patients according to the method of Anderson and McCarty (1950), using commercial C-reactive protein antiserum-Schieffelin. Other tests, including the erythrocyte sedimentation rate, were carried out at the same time. The laboratory aspects and the comparative value of these tests are the subject of a separate communication (Eastham, Szekely, and Davison (1958).

\section{Results}

The behaviour of the $\mathrm{C}$-reactive protein in the four clinical groups is shown in the Table.

Group A.-All patients with clear evidence of active rheumatic carditis gave a positive test for C-reactive protein.

TABLE I

C-REACTIVE PROTEIN IN RHEUMATIC FEVER AND RHEUMATIC HEART DISEASE

\begin{tabular}{c|c|c|c|c}
\hline Clinical Group & $\begin{array}{c}\text { No. of } \\
\text { Patients }\end{array}$ & $\begin{array}{c}\text { Average } \\
\text { Age (yrs) }\end{array}$ & C-Reactive Protein \\
\cline { 2 - 4 } & Present & Absent \\
\hline (A) Active Carditis & 12 & 26 & 12 & 0 \\
\hline $\begin{array}{c}\text { Chronic valvu- } \\
\text { lar disease } \\
\text { No certain evi- } \\
\text { dence of } \\
\text { rheumatic } \\
\text { activity } \\
\text { Past or present } \\
\text { cardiac } \\
\text { failure }\end{array}$ & 61 & 40 & 47 & 14 \\
\hline (C) $\begin{array}{c}\text { Chronic valvu- } \\
\text { lar disease } \\
\text { No certain evi- } \\
\text { dence of } \\
\text { rheumatic } \\
\text { activity } \\
\text { No cardiac } \\
\text { failure }\end{array}$ & 134 & 32 & 11 & 123 \\
\hline (D) \begin{tabular}{c} 
Chorea only.. \\
\hline
\end{tabular} & 8 & 12 & 0 & 8 \\
\hline
\end{tabular}


Six of these patients were treated with prednisone for 10 to 73 days. Clinical improvement was rapid and the C-reactive protein disappeared from the serum in all six patients between 6 and 18 days after the start of the treatment. In four patients, the abnormal protein reappeared between 8 and 14 days after discontinuation of prednisone: in three of these the test became negative again within a fortnight without further treatment, but in the fourth patient it remained positive and she had a clinical relapse within a month.

The behaviour of the $\mathrm{C}$-reactive protein in a patient treated with prednisone is illustrated in the Figure.

Six patients were treated with salicylates only and here the C-reactive protein persisted for 4 to 6 weeks.

Group B.-C-reactive protein was present in 47 of the 61 patients with chronic rheumatic heart disease whose cardiac condition was judged to be progressive but in whom no certain clinical criteria of rheumatic activity could be found. Of the 47 patients, 25 were experiencing cardiac failure, associated with bronchitis in four and embolic episodes in five, at the time of the initial laboratory investigation. Two further patients had embolic episodes without cardiac failure.

In seven patients the $\mathrm{C}$-reactive protein test became negative after the signs of cardiac failure had disappeared, but in seven others it persisted in spite of comparable clinical improvement.

In the remaining eleven patients with cardiac failure only single tests were done.
In the two patients who had embolic episodes without cardiac failure, there was a reversal from the initial positive test to a negative within a week.

Of the fourteen patients in this group with a negative $\mathrm{C}$-reactive protein test five were suffering from cardiac failure; none of these had respiratory infection or embolic episodes.

Group C.-Of the 134 patients with chronic rheumatic heart disease who were considered clinically to be in a quiescent stage, eleven had a positive C-reactive protein test. Two of these had bronchitis and one had a pulmonary infarct. A fourth patient had arthralgia and 6 months later developed rheumatoid arthritis. In two patients there had been a recent change from sinus rhythm to atrial fibrillation. The remaining five patients were in every way comparable to the large number of patients in this group in whom C-reactive protein was absent.

Group D.-In the eight patients who had chorea and no other rheumatic manifestations, the C-reactive protein test was invariably negative.

\section{C-Reactive Protein and Aschoff Bodies}

There were seven patients in whom auricular biopsies were available for examination after mitral valvotomy who also had pre-operative C-reactive protein determinations. Five had a positive test and in four of these Aschoff bodies were demonstrated. Aschoff bodies were also found in two patients with negative C-reactive protein tests.

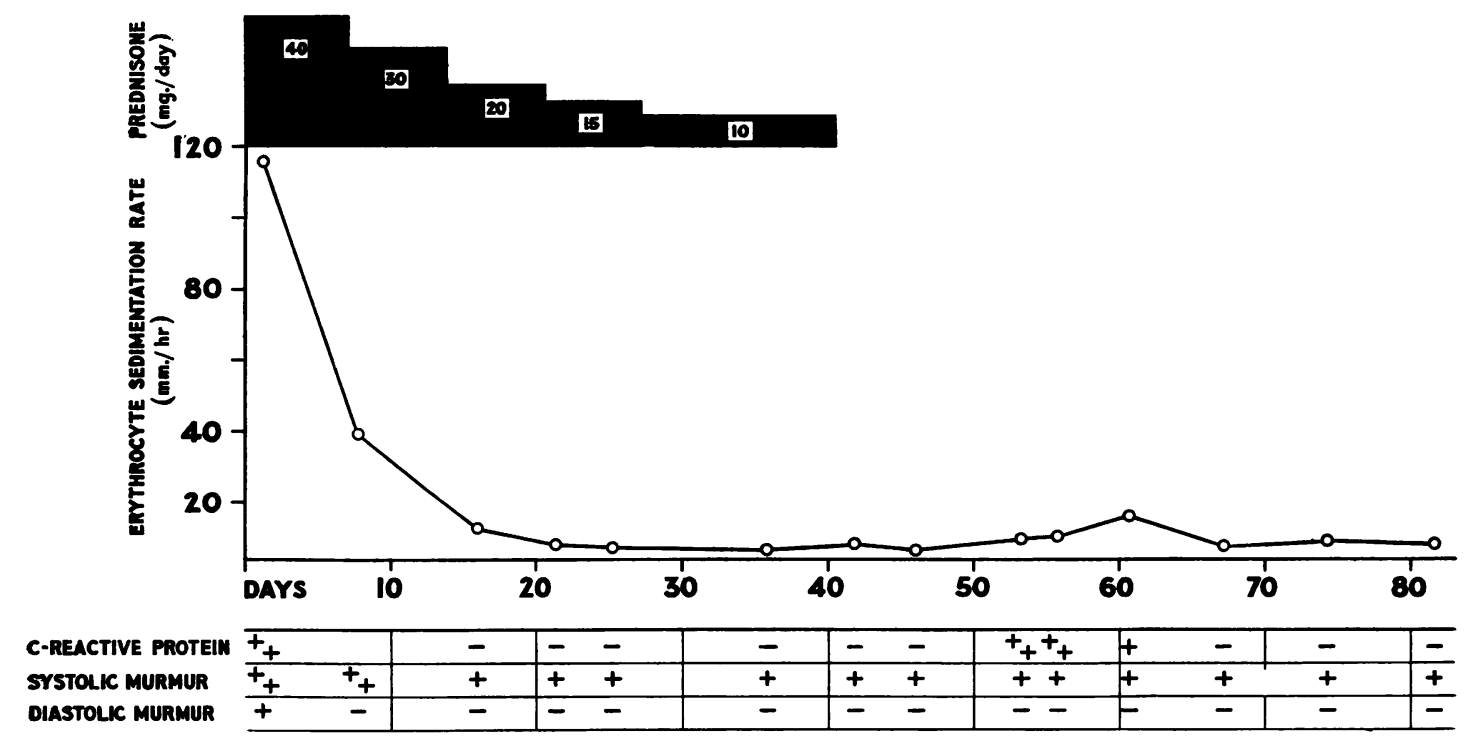

FIGURE.-Behaviour of C-reactive protein in a case of active rheumatic carditis treated with prednisone. 
Two further patients came to autopsy: one had a negative $\mathrm{C}$-reactive protein test in the presence of many Aschoff bodies in the left atrium and left ventricle, and in the other the $\mathrm{C}$-reactive protein test was positive and no Aschoff bodies were found in the heart muscle.

\section{Discussion}

Anderson and McCarty (1950) stated that the detection of C-reactive protein in the serum was the most consistently positive laboratory finding in the presence of rheumatic activity. A similar opinion was later expressed by Bunim, Kuttner, Baldwin, and McEwen (1952) and Stollerman, Glick, Patel, Hirschfield, and Rusoff (1953). Hill (1952) also stated that the C-reactive protein faithfully reflected the fluctuations in the activity of the disease. However, this protein has not been invariably present in active rheumatic disease (Shackman, Heffer, and Kroop, 1954). In the present series C-reactive protein could be detected in every case where the clinical findings indicated an active rheumatic process.

Treatment with prednisone led to disappearance of the C-reactive protein within 3 weeks and there was a parallel clinical improvement in all patients so treated. Similar results have been obtained by others (Bunim and others, 1952; Stollerman, Glick, and Anderson, 1954; McEwen, 1955; Bunim, 1956; Rahman and Mozziconacci, 1957). However, opinions have differed whether this indicates complete suppression of rheumatic activity or not. According to McEwen and Ziff (1955), the C-reactive protein test is not a reliable guide to rheumatic activity during hormone treatment because of the direct effect of the hormones on this protein. On the other hand, there is evidence to show that the disappearance of C-reactive protein from the serum during treatment with adreno-cortical hormones or with salicylates is due to suppression of the inflammatory process rather than to a primary effect of these agents upon the metabolism of C-reactive protein (Stollerman and others, 1954; Hedlund, Frisk, and Bucht, 1956). Stollerman and others (1953) also emphasize that the persistence of C-reactive protein during treatment indicates incomplete suppression of the inflammatory process and that treatment should be continued until the positive reaction becomes negative. Yocum and Doerner (1957) also found that large doses of hormones in rheumatic fever did not cause the C-reactive protein to disappear as long as rheumatic activity was clinically evident. Rahman and Mozziconacci (1957) found that the C-reactive protein persisted longer in patients treated with salicylates than in the hormone-treated group, and this is in keeping with our own observations.

The C-reactive protein was found to reappear in the serum after discontinuation of hormone therapy (Ziegra and Kuttner, 1951; Stollerman and others, 1953; Shackman and others, 1954). Bunim (1956) reported that, when hormonal administration was discontinued, the C-reactive protein temporarily reappeared in 40 per cent. of cases. Rahman and Mozziconacci (1957) found a reversal of the Creactive protein test from negative to positive in 27 per cent. of the cases. We also found that C-reactive protein reappeared after discontinuing prednisone in four cases. Dawson (1957) stated that, in those cases which relapsed, the C-reactive protein test became positive a few days before the relapse became clinically apparent. Shackman and others (1954) expressed the opinion that only continued observation for at least 3 weeks, without re-institution of therapy, can differentiate between a rebound and persisting rheumatic activity.

When chorea was the only rheumatic manifestation, the C-reactive protein was invariably absent. This is in keeping with the findings of previous investigators (Anderson and McCarty, 1950; Stollerman and others, 1953; Wood and McCarty, 1954? Dawson, 1957; Rahman and Mozziconacci, 1957) Shackman and others (1954) reported two patient with chorea who had a positive C-reactive protein test but both had concurrent carditis. These authors stressed that a positive test in chorea should suggest an associated carditis and that a negative test is presumptive evidence of its absence.

The present observations suggest that single C-reactive protein determinations in chronic rheumatic heart disease in the absence of clinical evidence of rheumatic activity may be misleading, but that repeated tests interpreted in conjunction with the clinical progress may be helpful in the assessment and management of these cases. Those patients in whom the disease progressed very little, if at all, over a period of years, as judged by the lack of symptoms, absence of progressive cardiac enlargement, and cardiac failure, showed as a rule repeatedly negative C-reactive protein tests. Shackman and others (1954) also stated that a negative C-reactive protein test was an accurate measure of the inactive state. A clinical analysis of the cases included in Group B showed that the 47 patients who had an initial or persistent positive C-reactive protein test represented a more advanced condition within the group, as judged by exercise tolerance and cardiac size, than the fourteen patients without $\mathrm{C}$-reactive protein. In view of the non-specific nature of the C-reactive protein test, we do not feel justified in concluding 
how many, if any, of these patients had in fact active rheumatic carditis. However, it would appear from the present study that a persistently positive Creactive protein test in chronic rheumatic heart disease is a significant finding because it is more often than not associated with progressive cardiac enlargement and clinical deterioration.

Although C-reactive protein is usually present in congestive cardiac failure with rheumatic activity (Bywaters, 1956), the findings of Elster and others (1956) tend to show that congestive heart failure per se may give rise to a positive test. On the other hand, Stollerman and others (1953) and McEwen and Ziff (1955) believe that congestive cardiac failure is not responsible for the appearance of this protein. In the present series, C-reactive protein disappeared from the serum in several patients after the signs of cardiac failure had cleared up; in other patients it persisted in spite of comparable clinical improvement, and yet in other cases it was not present at all during the stage of cardiac failure. These findings suggest that congestive cardiac failure per se is not likely to be responsible for the production of $\mathrm{C}$-reactive protein. Embolic episodes or respiratory infection are known to account for a positive test (Hedlund, 1947; Roantree and Rantz, 1955; Elster and others, 1956; Yocum and Doerner, 1957), and these complications were present in some of our patients.

Several patients with a positive $C$-reactive protein test were pregnant, but in our experience pregnancy does not influence the behaviour of this protein. In 48 normal pregant women at various stages of their pregnancy, the test was invariably negative. This is in agreement with the findings of Hedlund (1947) and Shetlar, Bullock, Shetlar, and Payne (1955).

Elster and Wood (1955) reported on the lack of correlation between pre-operative $\mathrm{C}$-reactive protein tests and the presence of Aschoff bodies in auricular biopsies obtained from patients undergoing mitral valve surgery. We have also encountered instances of negative C-reactive protein tests in the presence of Aschoff bodies. Elster and Wood (1955) suggest that, in these cases, the pathological process is not sufficiently active to lead to the production of C-reactive protein, and that the degree of rheumatic activity may have little or no clinical significance.

\section{Summary}

The behaviour of C-reactive protein was studied in patients with rheumatic fever and rheumatic heart disease at various stages of the disease process.

$\mathrm{C}$-reactive protein was always present in active rheumatic carditis and proved a useful guide in the management of these cases.

In cases of isolated chorea, C-reactive protein was invariably absent and this appeared to be good evidence of the absence of concurrent carditis.

The value and limitations of the test in chronic heart disease in the absence of obvious clinical evidence of rheumatic activity are discussed.

Our thanks are due to Dr. W. G. A. Swan and Dr. F. Jackson for their help and criticism. We should also like to thank Dr. G. Davison, Dr. G. Richardson, and Dr. C. Cooper for allowing us to study some of their patients. The mitral valve operations referred to in the paper were performed by Mr. G. A. Mason. We are grateful to Dr. I. Rannie for the reports on the auricular biopsies and to Dr. B. E. Tomlinson for the autopsy findings.

\section{REFERENCES}

Anderson, H. C., and McCarty, M. (1950). Amer. J. Med., 8, 445. Biörck, G. (1955). J. chron. Dis., 1, 591

Bunim, J. J. (1956). Ibid., 3, 230.

Bunim, J. J. (1956). Ibid., 3, 230. J. S., and McEwen, C. (1952). K. Amer. med. Ass., 150, 1273 .

Bywaters, E. G. L. (1956). Circulation, 14, 1153.

Dawson, S. F. (1957). Arch. Dis. Childh., 32, 454

Eastham, R. D., Szekely, P., and Davison, K. (1958). Ann. rheum. Dis., 17, 319.

Elster, S. K., Braunwald, E., and Wood, H. F. (1956). Amer. Heart J., 51, 533.

- and Wood, H. F. (1955). Ibid., 50, 706

Hedlund, P. (1947). Acta med. scand., Suppl. 196, p. 579. Frisk, A. R., and Bucht, H. (1956). Scand. J. clin. Lab. Invest. 8, 207.

Hill, A. G. S. (1952). Lancet, 2, 558

Jones, T. D. (1944). J.Amer. med. Ass., 126, 481.

McEwen, C. (1955). Med. Clin. N. Amer., 39, 353.

McEwen, Ciff, M. (1955). Ibid., 39, 765.

Mortimer, E. A., Jr., and Rammelkamp, C. H., Jr. (1956). Circulation, 14, 1144.

Rahman, S., and Mozziconacci, P. (1957). Sem. Hôp. Paris, 33, 2179.

Roantree, R. J., and Rantz, L. A. (1955). A.M.A. Arch. intern. Med., 96, 674 .

Roberts, E. (1954). Med. Clin. N. Amer., 38, 1705.

Shackman, N. H., Heffer, E. T. and Kroop. I. G. (1954). Amer. Heart J., 48, 599.

Shetlar, M. R., Bullock, J. A., Shetlar, C. L., and Payne, R. W. (1955). Proc. Soc. exp. Biol. (N.Y.), 88, 107.

Stollerman, G. H., Glick, S. J., and Ánderson, H. C. (1954). Ibid., 87, 241 .

77, Patel, D. J., Hirschfeld, I., and Rusoff, J. H. (1953). Amer. J. Med., 15, 645.

Wood, H. F., and McCarty, M. (1954). Ibid., 17, 768.
Yocum, R.S., and Doerner, A. A. (1957). A.M.A. Arch. intern. Med., $99,74$.

Ziegra, S. R., and Kuttner, A. G. (1951). Amer. J. med. Sci., 222, 516.

\section{Protéine C-réactive dans la maladie de Bouillaud}

RÉSUMÉ

On étudia le comportement de la protéine C-réactive chez des malades atteints de maladie de Bouillaud à de différentes périodes évolutives.

La protéine C-réactive fut toujours présente dans la cardite rhumatismale active et se révéla utile dans le maniement de ces cas.

Dans des cas de chorée seule, la protéine C-réactive fut invariablement absente, fournissant ainsi une preuve d'absence d'une cardite concomitante.

On discute la valeur et les limitations de cette épreuve dans la maladie rhumatismale chronique du coeur en 
l'absence de preuves cliniques apparentes d'activité rhumatismale.

\section{Proteina C-reactiva en la enfermedad de Bouillaud Sumario}

Se estudió el comportamiento de la proteina C-reactiva en los pacientes con la enfermedad de Bouillaud en diferentes períodos evolutivos.

La proteina C-reactiva se pudo siempre demostrar en la presencia de carditis reumática activa y se reveló útil en el manejo de estos casos.

En casos de corea sola, la ausencia invariable de la proteina C-reactiva ofrecía una prueba válida de ausencia de una carditis concomitante.

Se discute el valor y las limitaciones de esta reacción en la enfermedad reumática crónica del corazón en la ausencia de pruebas clínicas aparentes de actividad reumática. 